Вип. 1, 2019

УДК 621.316.925

В. Г. Гапанович

Національний університет “Львівська політехніка”, кафедра електроенергетики та систем управління, gapanovich@ukr.net

3. М. Бахор

Національний університет “Львівська політехніка", кафедра електроенергетики та систем управління, zbakhor@gmail.com

\title{
ЕКСПЕРИМЕНТАЛЬНІ ДОСЛІДЖЕННЯ ДИНАМІЧНИХ ПРОЦЕСІВ СТАТИЧНОГО ТИРИСТОРНОГО КОМПЕНСАТОРА ДЛЯ СИСТЕМИ ЕЛЕКТРОПОСТАЧАННЯ ШАХТНОГО НАВАНТАЖЕННЯ
}

https://doi.org/10.23939/sepes2019.01.017

(C) Гапанович В. Г., Бахор 3. М., 2019

3 метою покращення показників якості електроенергії в мережі живлення 35 кВ шахтного навантаження, що живиться від шин районної підстанції 330/220/110/35 кВ “Нововолинська" Західної енергосистеми, впроваджено статичний тиристорний компенсатор реактивної потужності (СТК). Сумісна робота СТК і пристрою регулювання напруги під навантаженням (РПН) трансформаторів підстанції дають змогу вирішити завдання комплексного керування режимом роботи системи електропостачання (СЕП) шахтного навантаження. Автори розробили структурну схему регулятора СТК пропорційної дії та виготовили дослідний зразок регулятора СТК, який дозволяє 3 високою точністю стабілізувати напругу в місці під'сднання СТК. Для оцінювання якості перехідного процесу, спричиненого збуреннями параметрів режиму СЕП шахтного навантаження, одержано передавальну функцію регулятора СТК 3 урахуванням передавальних функцій його ланок. За прийнятих значень сталої часу активного фільтра дослідного зразка регулятора показано, що перехідний процес у його схемі відбувається асимптотично із прийнятними сталими часу. Експериментальні дослідження динамічних характеристик СТК, керованого розробленим регулятором, пітвердили, що стійка робота СТК забезпечусться для всього діапазону сталих часу згасання регулятора.

Ключові слова: система електропостачання шахтного навантаження; статичний тиристорний компенсатор; динамічні характеристики.

Постановка проблеми та їі зв'язок із важливими науковими завданнями

Для покращення показників якості електроенергії в мережі 35 кВ, основним навантаженням якої $\epsilon$ шахти Львівсько-Волинського басейну, на підстанції "Нововолинська" 330/220/110/35 кВ Західної енергосистеми, від шин 35 кВ якої живиться шахтна мережа, впроваджено статичний тиристорний 
компенсатор реактивної потужності (СТК). Сумісна робота СТК і пристроїв регулювання напруги під навантаженням (РПН) трансформаторів підстанції дають змогу вирішити завдання комплексного керування режимом роботи системи електропостачання (СЕП) шахтного навантаження. Автори розробили структурну схему регулятора СТК пропорційної дії та виготовили дослідний зразок регулятора СТК, який дає можливість із високою точністю стабілізувати напругу в місці під’єднання СТК [1].

\section{Актуальність та доцільність роботи}

Компенсація відхилень і коливань напруги в шахтних мережах підвищує продуктивність і надійність роботи їх електроприймачів. Покращити вказані показники якості електроенергії можна, застосовуючи СТК із регулятором пропорційної дії. Тому розроблення структурної та принципової схеми регулятора пропорційної дії, виготовлення дослідного зразка і перевірка його працездатності в різних режимах $\epsilon$ актуальним завданням. Моделювання систем електропостачання різкозмінного навантаження із СТК, з регуляторами різного типу, здійснено у багатьох працях: у [4] розглянуто питання моделювання гнучких систем пересилання змінного струму (FACTS) на базі тиристорного компенсатора реактивної потужності (SVC TCR) паралельного типу; алгоритми роботи систем FACTS із комбінованими фільтрами розроблено в [5]; у [6] запропоновано нову архітектуру модуля оброблення і комутації сигналів (DMS), яка дає змогу ефективніше регулювати напругу та реактивну потужність у системах із СТК; моделювання режимів роботи компенсатора СТК із регулятором пропорційної дії виконано у [7]; в [8] подано модель компенсатора СТК на основі змінного імпедансу як функції кута керування тиристорів ТРГ; застосування системи регулювання СТК із пропорційно-інтегрально-диференціюючим (PID) регулятором і додатковим контролером нечіткої логіки (FLC) дає змогу збільшити запас стійкості електроенергетичної системи [9]. Автори не виявили в періодичній літературі експериментальних досліджень динамічних характеристик СТК із регулятором пропорційної дії, який є підсистемою комплексної системи керування режимом роботи СЕП шахтного навантаження.

\section{Мета і завдання роботи}

Мета роботи - покращення показників якості електроенергії в системі електропостачання шахтного навантаження за допомогою СТК із регулятором пропорційної дії.

Завдання роботи: дослідження режимів СТК із запропонованим регулятором на діючій підстанції "Нововолинська", від шин якої живиться мережа із шахтним навантаженням; перевірка стійкості роботи СТК і працездатності його регулятора в динамічних режимах.

\section{Виклад основного матеріалу}

На підстанції 330/220/110/35 кВ “Нововолинська” Західної енергосистеми для стабілізації напруги на шинах 35 кВ, від яких живиться шахтне навантаження, встановлено СТК на базі наявної на підстанції БСК 35 кВ потужністю 31 МВ·А і ТКРМ-20/6 (20 МВ· А, 6 кВ). Схему під'єднання СТК наведено на рис. 1.

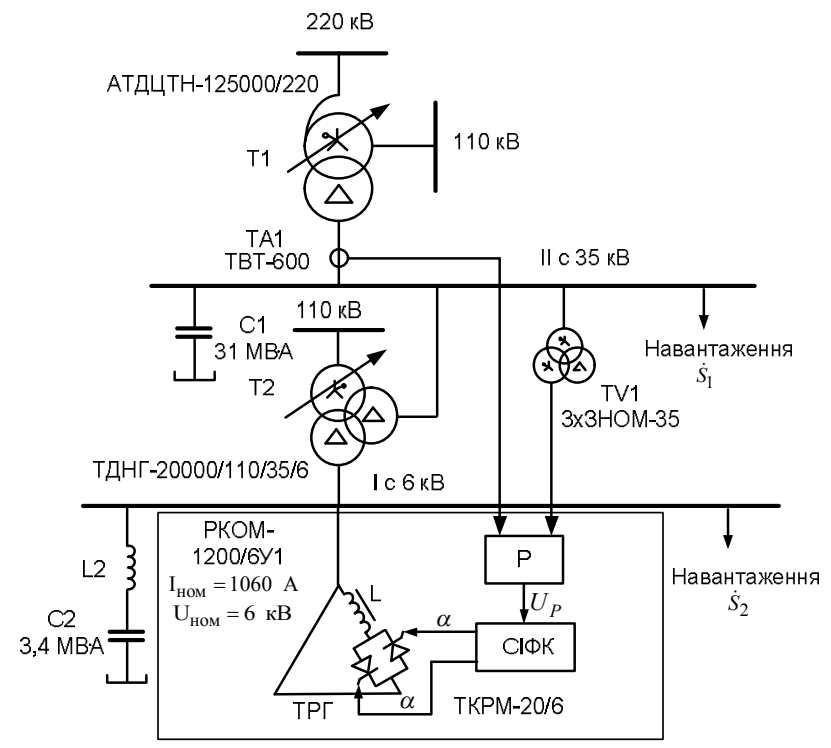

Рис. 1. Принщиипова схема nідстанųiї із CTK 
На підставі принципу пропорційного регулювання за відхиленням напруги $\Delta U_{1}$ i струму $\Delta I_{1}$ [1] розроблено структурну схему регулятора СТК (рис. 2) [1-3].

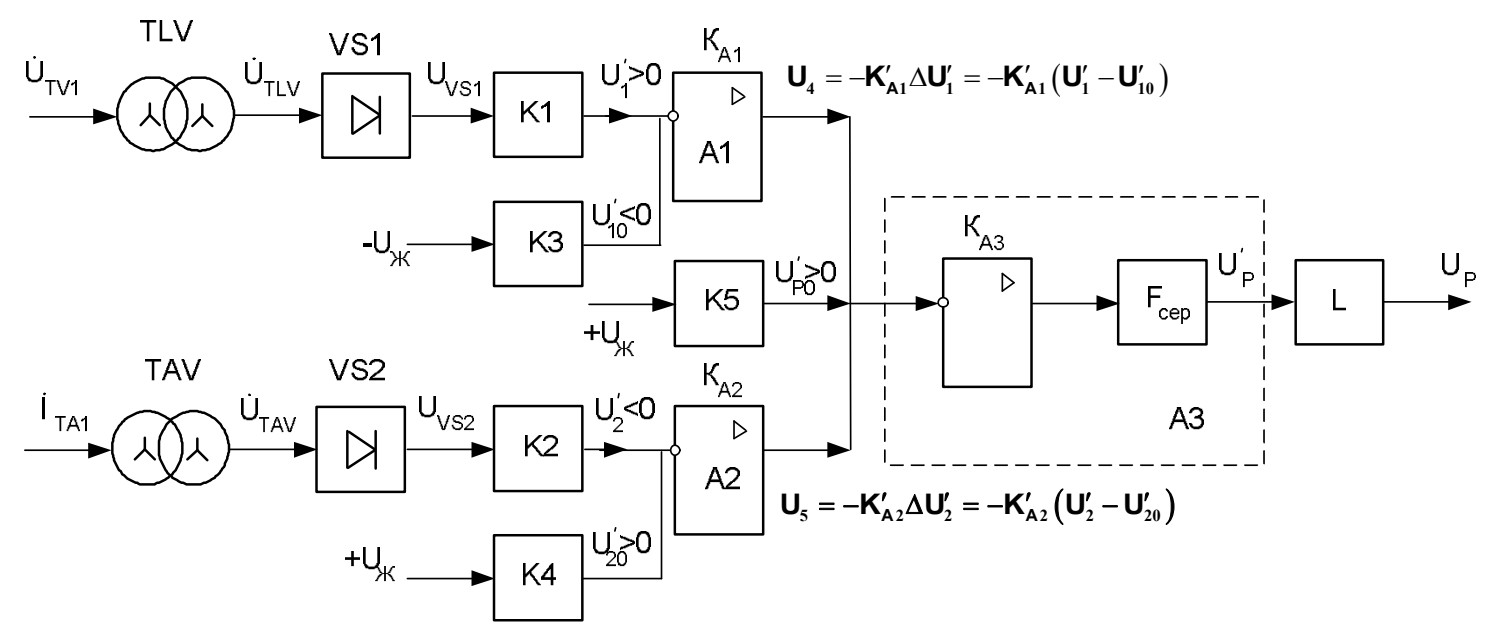

Рис. 2. Структурна схема регулятора СТК

На вхід регулятора (рис. 2) від трансформатора напруги TV1 (рис. 1), який під’єднаний до II секції шин $35 \mathrm{\kappa B}$, подаються три лінійні напруги $\dot{U}_{T V 1}$, а від трансформаторів струму ТА1 (ввід 35 кВ) - три фазні струми $\dot{I}_{T A 1}$. Як видно з рис. 2, канали перетворення параметрів регулювання (напруги і струму) на відповідні уніполярні напруги $U_{1}^{\prime}$ і $U_{2}^{\prime}$ однакові.

Вхідні напруги (струми) надходять на трифазні групи проміжних трансформаторів TLV (TAV), які узгоджують параметри вхідних величин регулятора із допустимими вхідними параметрами підсилювачів $\mathrm{A} 1$ i A2. Напруги на виході трансформаторних груп $\dot{U}_{T L V}\left(\dot{U}_{T A V}\right)$ випрямляються трифазними випрямлячами VS1 (VS2) і через потенціометри-подільники К1 (К2) подаються на інверсні входи підсилювачів А1 (A2). До цих самих входів підсилювачів через потенціометри-подільники К3 (К4) підводять початкові (опорні) напруги $U_{10}^{\prime}\left(U_{20}^{\prime}\right)$, що відповідають початковим параметрам режиму системи електропостачання шахтного навантаження - $U_{10}\left(I_{10}\right)[3,4]$. На виходах підсилювачів A1 (A2) формуються напруги $U_{4}\left(U_{5}\right)$, пропорційні до неузгодженостей параметрів регулювання $\Delta U_{1}\left(\Delta I_{1}\right)$. Напруги із виходів А1 (A2) надходять на інверсний вхід підсилювача А3, на нього ж подається опорна напруга $U_{P O}^{\prime}$, яка відповідає початковій напрузі $\mathrm{U}_{\mathrm{PO}}$ на виході регулятора, якщо $U_{4}=U_{5}=0$. Напруга із виходу підсилювача А 3 надходить на вхід активного $R-C$ фільтра $F_{c e p}$, що виділяє середне значення напруги $U_{P}^{\prime} .3$ виходу фільтра напруга подається на пристрій обмеження $L$, на виході якого формується напруга регулятора $U_{P}$.

Відповідно до структурної схеми регулятора СТК, яка наведена на рис. 2, запишемо співвідношення для параметрів режиму (середні значення параметрів) регулятора:

$$
\begin{array}{lll}
\dot{U}_{T L V}=K_{T L V} \dot{U}_{T V 1} ; & \dot{U}_{T A V}=\sqrt{3} K_{T A V} \dot{I}_{T A 1} ; & \\
U_{V S 1}=\sqrt{3} K_{c e p} U_{T L V} ; & U_{V S 2}=\sqrt{2} K_{c e p} U_{T A V} ; & U_{P}^{\prime}=K_{A 3}\left(U_{4}-U_{5}-U_{P O}^{\prime}\right) ; \\
U_{1}^{\prime}=K_{1} U_{V S 1} ; & U_{2}^{\prime}=K_{2} U_{V S 2} ; & \left|U_{P \min }\right| \leq\left|U_{P}\right| \leq\left|U_{P \max }\right| . \\
U_{4}=K_{A 1}\left(U_{1}^{\prime}-U_{10}^{\prime}\right)=K_{A 1} \Delta U_{1}^{\prime} ; & U_{5}=K_{A 2}\left(U_{2}^{\prime}-U_{20}^{\prime}\right)=K_{A 2} \Delta U_{2}^{\prime} ;
\end{array}
$$

Відповідно до закону регулювання $\Delta U_{P}=K_{U} \Delta U_{1}-K_{I} \Delta I_{1}[2,3]$ напругу на виході регулятора визначимо за виразом

$$
U_{p}=U_{P 0}+K_{U P} \Delta U_{T V 1}-K_{I P} \Delta I_{T A 1}
$$


де

$$
\begin{gathered}
\Delta U_{P}=U_{P}-U_{P O} ; \\
\Delta U_{T V 1}=U_{T V 1}-U_{T V 10} ; \\
\Delta I_{T A 1}=I_{T A 1}-I_{T A 10} ;
\end{gathered}
$$

$K_{U P}, K_{I P}$ - коефіцієнти підсилення приростів параметрів регулювання за напругою і струмом, $\Delta U_{P}-$ приріст напруги на виході регулятора.

3 огляду на те, що

$U_{10}^{\prime}=U_{1}^{\prime}$, якщо $U_{T V 1}=U_{T V 10} ; U_{20}^{\prime}=U_{2}^{\prime}$, якщо $I_{T A 1}=I_{T A 10} ; U_{P}=U_{P O}$, якщо $U_{4}=U_{5}=0$.

3 (1) з урахуванням (6) одержимо вираз для визначення $\Delta U_{P}$

$$
\begin{gathered}
U_{10}^{\prime}=\sqrt{2} K_{T L V} K_{1} K_{c e p} U_{T V 10} ; \\
U_{20}^{\prime}=\sqrt{6} K_{T A V} K_{2} K_{c e p} I_{T A 10} ; \\
U_{P 0}^{\prime}=\frac{-U_{P 0}}{K_{A 3}} ; \\
\Delta U_{P}=\sqrt{2} K_{T L V} K_{1} K_{A 1} K_{A 3} K_{c e p} \Delta U_{T V 1}-\sqrt{6} K_{T A V} K_{2} K_{A 2} K_{A 3} K_{c e p} \Delta I_{T A 1},
\end{gathered}
$$

де $K_{A 1}, K_{A 2}, K_{A 3}$ - коефіцієнти передачі підсилювачів А1, А2, А3.

Зі співвідношень (2), (3) і (10) отримаємо вирази для визначення коефіцієнтів підсилення приростів параметрів регулювання за напругою і струмом

$$
K_{U P}=\sqrt{2} K_{T L V} K_{1} K_{A 1} K_{A 3} ; \quad K_{I P}=\sqrt{6} K_{T A V} K_{2} K_{A 2} K_{A 3} .
$$

У наведених виразах коефіцієнти $K_{1}, K_{2}$ не перевищують одиниці.

Для аналізу якості перехідного процесу в СЕП шахтного навантаження із СТК необхідно одержати передавальну функцію регулятора СТК з урахуванням передавальних функцій його ланок.

За збурень параметрів режиму із порівняно невеликою частотою $\Delta \vec{\Pi}(\mathrm{p})=\left(\Delta U_{1}(p), \Delta I_{1}(p)\right)$ можна вважати, що всі передавальні функції ланок регулятора (рис. 2), за винятком фільтра $F_{c e p}$, дійсні й дорівнюють відповідним коефіціснтам передачі цих ланок. Для приростів параметрів регулювання згідно із (10) запишемо рівняння регулятора в операторній формі за поштовхів уніполярних приростів напруги $\Delta U_{T V}$ і струму $\Delta I_{T A}$

$$
\Delta U_{p}(p)=\sqrt{2} K_{1} K_{T L V} K_{A 1} K_{A 3} K_{F}(p) K_{c e p} \Delta U_{T V 1}(p)-\sqrt{6} K_{2} K_{T A V} K_{A 2} K_{A 3} K_{F}(p) K_{c e p} \Delta I_{T A 1}(p),
$$
де $K_{F}(p)$ - передавальна функція фільтра $F_{c e p}$.

Оскільки трансформатор TAV є джерелом напруги, яка випрямляється випрямлячем VS2, то його враховують дійсним коефіцієнтом передачі $K_{T A V}$.

Фільтр $F_{\text {сер }}$ виконано у вигляді паралельної $R$ - $C$ ланки в колі від'ємного зворотного зв'язку підсилювача А3 (інерційна ланка першого порядку)

$$
K_{F}(p)=\frac{1}{\left(T_{F} p+1\right)}
$$

де $T_{F}=R_{F} C_{F}-$ стала часу фільтра.

Остаточно, в операторній формі, рівняння регулятора має вигляд

$$
\Delta U_{P}(p)=K_{U P}(p) \Delta U_{T V 1}(p)-K_{I P}(p) \Delta I_{T A 1}(p),
$$

а вирази коефіцієнтів підсилення приростів параметрів регулювання за напругою і струмом відповідно:

$$
K_{U P}(p)=\frac{\sqrt{2} K_{1} K_{T L V} K_{A 1} K_{A 3}}{\left(T_{F} p+1\right)} ; K_{I P}(p)=\frac{\sqrt{6} K_{2} K_{T A V} K_{A 2} K_{A 3}}{\left(T_{F} p+1\right)} .
$$


3 огляду на співвідношення (1) та (15) одержуємо

$$
\Delta U_{P}(p)=\frac{K_{U P}}{\left(T_{F} p+1\right)} \Delta U_{T V 1}(p)-\frac{K_{I P}}{\left(T_{F} p+1\right)} \Delta I_{T A 1}(p) .
$$

Для оцінки якості перехідного процесу, тобто визначення $\Delta U_{P}(t)$, задаємо дійсні розрахункові значення збурень вхідних параметрів [10].

Тоді прирости цих збурень та їх числові значення запишемо як

$$
\Delta U_{T V 1}=\frac{\Delta U_{1}^{(M)}}{K_{c e p} K_{T V 1}}=\Delta U_{T V 1 M . c e p}=0,807 B ; \quad \Delta I_{T A 1}=\frac{\Delta I_{1}^{(M)}}{K_{c e p} K_{T A 1}}=\Delta I_{T A 1 M . c e p}=0,189 B .
$$

У результаті одержимо операторне зображення збурення

$$
\Delta U_{P}(p)=K_{U P} \Delta U_{T V 1 M . c e p} \frac{1}{\left(T_{F} p+1\right)}-K_{I P} \Delta I_{T A 1 M . c e p} \frac{1}{\left(T_{F} p+1\right)} .
$$

Оригінал функції визначаємо за виразом

$$
\Delta U_{P}(t)=\left(K_{U P} \Delta U_{T V 1 M . C P}-K_{I P} \Delta I_{T A 1 M . C P}\right)\left(1-e^{-t / T_{F}}\right)
$$

Як видно із (18), збурення $\Delta U_{P}(t)$ змінюється за експонентним законом і напруга на виході регулятора стабілізується за час $t_{y} \approx 3 T_{F}$.

У схемі регулятора передбачено активний фільтр $F_{\text {сер }}$ із регульованою сталою часу, яка змінюється у діапазоні $0,07 \div 0,21$ с. Отже, процес регулювання регулятора буде встановлюватися за час $\left(t_{y}\right)$, який лежить у межах $(0,2 \div 0,6) c$, що цілком прийнятно для шахтних навантажень.

Із викладеного видно, що перехідний процес у схемі регулятора СТК відбувається асимптотично зі сталою часу, необхідною для ефективної роботи СТК.

Для підтвердження вищевказаних положень проведено експериментальні дослідження динамічних характеристик СТК із регулятором пропорційної дії, під час яких знімали осцилограми: лінійних струмів ТРГ СТК $\left(i_{T P \Gamma(\mathrm{A})}, i_{T P \Gamma(\mathrm{C})}\right)$; лінійних струмів фільтра 5-ї гармоніки; міжфазних напруг I секції шин 6 кВ $\left(u_{A B(6)}, u_{B C(6)}, u_{C A(6)}\right)$; напруги нульової послідовності $\left(3 u_{0(6)}\right)$; напруги на виході регулятора СТК $\left(U_{P}\right)$. Запис зазначених параметрів режиму здійснювався під час стрибкоподібної зміни напруги на вході системи імпульсно-фазового керування (СІФК) СТК, що моделювалося “відмиканням” ТРГ і подаванням у момент "відмикання" на вхід СІФК напруги регулятора, який працював. Напруга на вході СІФК $\left(U_{P \min }\right)$ змінювалася у межах від $-8 B$ до $U_{P}$, що зумовлено режимом розглянутої системи електропостачання.

Під час експериментів отримано велику кількість осцилограм, аналіз яких показав, що стійка робота СТК забезпечується для всього діапазону $(0,07 \div 0,21$ с) сталих часу згасання регулятора.

На рис. 3 наведено одні із найхарактерніших осцилограм, які отримано за найбільшої сталої часу регулятора $-0,21 \mathrm{c}$.

На осцилограмі А (рис. 3) показано струми ТРГ СТК і струми фільтра 5-ї гармоніки, а на осцилограмі В (рис. 3) - напругу на шинах 6 кB, напругу нульової послідовності мережі 6 кВ і напругу на виході регулятора. На обох осцилограмах позначено характерні моменти часу. До моменту часу $t_{1}$ проходження сигналу регулятора на вхід СІФК СТК було заблоковано командою “замкнений”, а напруга на шинах 6 кВ становила 6,79 кВ (осц. В, рис. 3), що за уставки регулятора $U_{60}=6,1 \kappa B$ спричиняло доволі велике відхилення напруги регулятора $\Delta U_{P}$. Це призводило до збільшення напруги на виході фільтра регулятора до величини $U_{P}^{\prime} \approx 0$, що у разі відсутності пристрою обмеження $L$ (рис. 2) могло б призвести до перевантаження реактора СТК за струмом. Застосування зазначеного пристрою обмежувало напругу на виході регулятора $\left(U_{P \max }\right)$ до значення $-2,5$ В, що відповідає куту керування тиристорів 
120 ел. град. і струму реактора 1000 А. У момент часу $t_{1}$ на СІФК СТК подавалася команда “відімкнений”, яка знімала заборону на проходження сигналу з виходу регулятора і на вхід СІФК подавалася напруга $-2,5$ В, яка формувалася пристроєм обмеження за більших значень $\Delta U_{P}$ (осц. В, рис. 3). На рис. 3 (осц. А) видно характер зміни струмів ТРГ після проходження команди “відімкнений”. Максимальна амплітуда струму ТРГ становить 2212 А, що відповідає діючому значенню струму реактора $I_{L}=\frac{I_{T P \Gamma(C) \max }}{\sqrt{3} \cdot \sqrt{2}}=\frac{2212}{\sqrt{3} \cdot \sqrt{2}}=903 A<1000 A$ і свідчить про правильну роботу пристрою обмеження.

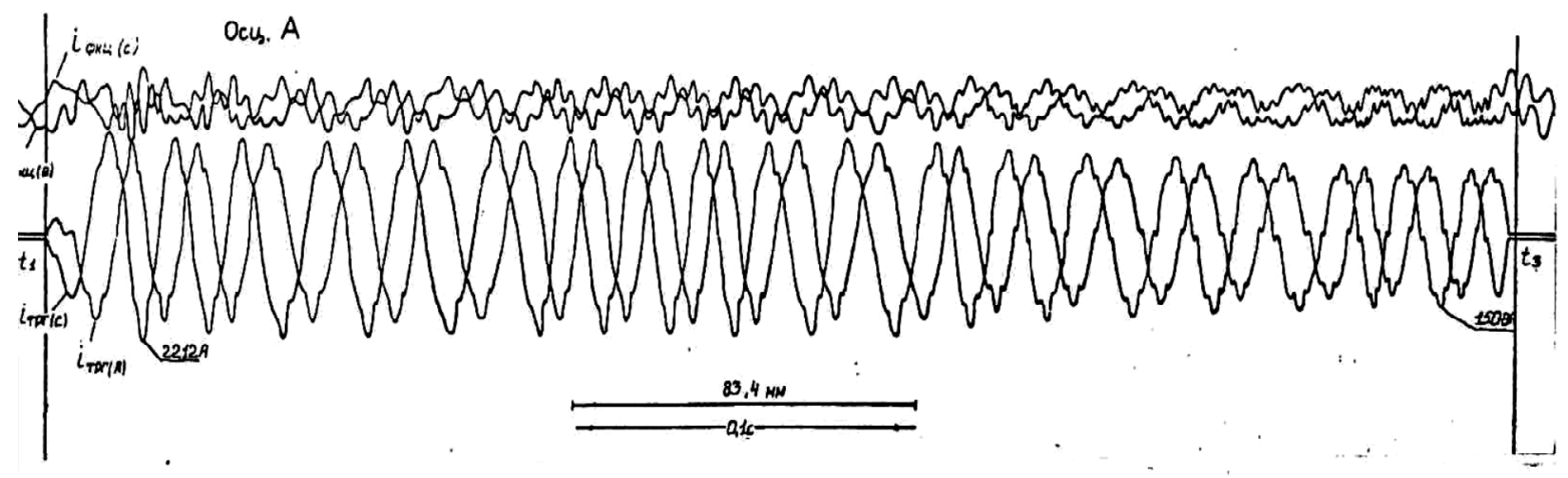

Ocus. B

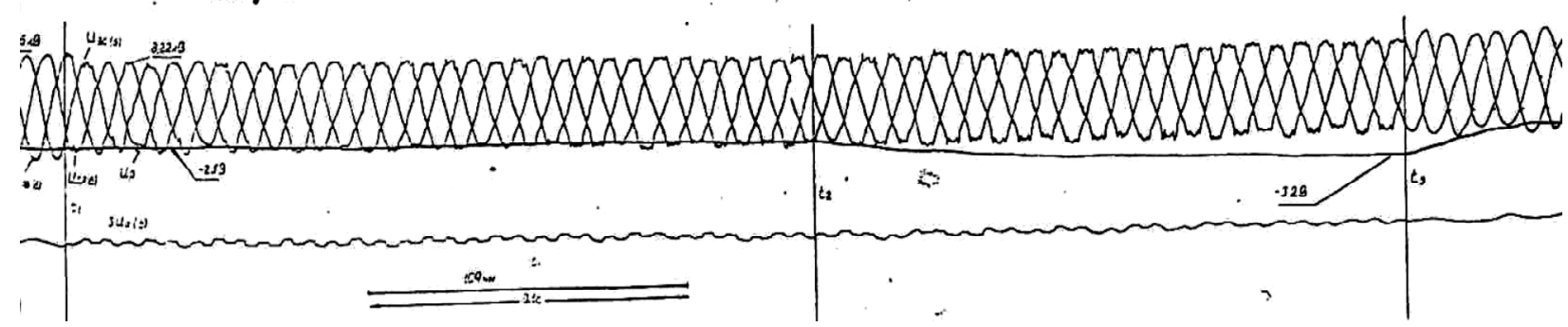

Рис. 3. Експериментальні осцилограми дослідження динамічних характеристик СТК

У розімкнутому трикутнику трансформатора напруги 6 кВ у момент “відмикання" ТРГ 3'являється напруга 3-ї гармоніки, що видно на осцилограмі $3 u_{0(6)}$ (осц. В, рис. 3). У момент часу $t_{1}$ напруга на виході регулятора $U_{P}=-2,5 B$ i не змінюється до моменту часу $t_{2}$, тому що виконується умова $\left|U_{P}^{\prime}\right|<\left|U_{P \max }\right|$. У момент часу $t_{2}$ спостерігається зміна напруги на виході регулятора, що свідчить про початок процесу регулювання СТК (осц. В, рис. 3), оскільки виконується умова $\left|U_{P}^{\prime}\right|>\left|U_{P \max }\right|$. До моменту часу $t_{3}$ регулювання закінчується, а напруга на виході регулятора стабілізується. У момент часу $t_{3}$ на СІФК подається команда “замкнений” і напруга на виході регулятора змінюється зі сталою часу самого регулятора, тоді як до моменту часу $t_{3}$ напруга на виході регулятора змінювалася зі сталою часу, зумовленою не тільки самим регулятором, але і системою електропостачання загалом. За осцилограмою (осц. В, рис. 3) можна визначити еквівалентну сталу часу розглянутої системи електропостачання шахтного навантаження iз регульованим СТК $\tau_{\ni}$ і сталу часу регулятора $\tau_{P}$ відповідно за формулами:

$$
\tau_{\ni}=\frac{t_{3}-t_{2}}{\ln \frac{U_{P}\left(t_{3}\right)}{U_{P}\left(t_{2}\right)}}=\frac{0,188}{\ln \frac{3,2}{2,5}}=0,762 c ; \tau_{\mathrm{P}}=\frac{t_{4}-t_{3}}{\ln \frac{U_{P}\left(t_{4}\right)}{U_{P}\left(t_{3}\right)}}=\frac{0,05}{\ln \frac{2,5}{3,2}}=0,202 c,
$$

де $U_{P}(t)$ - виміряна за осцилограмою (осц. В, рис. 3) напруга на виході регулятора в момент часу $t$. Як видно з наведених осцилограм, процес регулювання СТК $є$ асимптотичним і стійким. 


\section{Висновки}

Експериментальні дослідження динамічних режимів СТК із запропонованим регулятором, проведені на підстанції “Нововолинська”, дали змогу підтвердити результати попередніх теоретичних досліджень й отримати числові значення параметрів процесу регулювання СТК. Вибрані параметри елементів регулятора СТК забезпечують його стійку роботу й асимптотичний характер перехідних процесів у всьому діапазоні збурень параметрів режиму системи електропостачання.

\section{Список використаних джерел}

1. Разработка и исследование регулятора статического тиристорного компенсатора для подстаниии общего назначения / Ю. Е. Варецкий, В. Г. Гапанович, А. В. Жураховский, Ю. А. Кенс // Тезисы Научно-технической конференции “Создание и применение тиристорных преобразователей соизмеримой мощности”. Харьков, 1990.

2. Гапанович В. Г. Розробка регулятора статичного тиристорного компенсатора для системи електропостачання шахтного навантаження / В. Г. Гапанович, 3. М. Бахор // Вісник Найіонального університету “Львівська політехніка". 2016. - № 840: Електроенергетичні та електромеханічні системи. С. 24-30.

3. Гапанович В. Г. Методика розрахунку коефіціснтів підсилення регулятора статичного тиристорного компенсатора / В. Г. Гапанович, З. М. Бахор // Вісник Національного університету “Львівська політехніка". 2017. - № 870: Електроенергетичні та електромеханічні системи. - С. 22-26.

4. Xiao-Ping Z., Rehtanz C., Bikash P. (2006): Flexible AC Transmission Systems: Modelling and Control. 395 p. Chap.2, Springer Berlin Heidelberg New York. - Peэcun docmyny: http://www.springer.com/gp/book/9783642282409.

5 Hirofumi Akagi. Instantaneous power theory and applications to power conditioning / A. Hirofumi, E. Hirokazu Watanabe, A. Mauricio. New York (USA): IEEE Press book, 2007. 389 p. Pежсим достуny: http://www.gbv.de/dms/ilmenau/toc/522443818.PDF.

6. Miranda Vladimiro. An improved Fuzzy Inference System for Voltage/VAR control // IEEE Transactions on Power Systems, vol. 22, No. 4, November 2007. Режим docmyny: https://docslide.us/documents/an-improved-fuzzy-inferencesystem-for-voltagevar-control.html.

7. Modelling and Simulation of Static VAr Compensator (SVC) in Power System Studies by MATLAB / Houari Boudjella, Fatima Zohra Gherbi and Fatiha Lakdja // ACTA ELECTROTEHNICA, vol. 49, Number 4, 2008. P. 450-457. Pежим достуny: http://www.academia.edu/3411369/Modeling_and_simulation_of_static_var_compensator_with_Matlab.

8. Mark Ndubuka. NWOHU Department of Electrical/Computer Engineering, Federal University of Technology, Minna, Niger State, Nigeria. Voltage Stability Improvement using Static Var Compensator in Power Systems // Leonardo Journal of Sciences, Issue 14, January-June 2009. P. 167-172. Режим достуny: http://ljs.academicdirect.org.

9. Karpagam N., Devaraj D. Fuzzy Logic Control of Static Var Compensator for Power System Damping // International Journal of Electrical and Electronics Engineering, 3:10 2009. P. 625-631. Режим достуny: http://www.iust.ac.ir/find.php?item=35.8890.13122.en

10. Гапанович В. Г. Експериментальні дослідження процесу регулювання статичного тиристорного компенсатора для системи електропостачання шахтного навантаження / В. Г. Гапанович, 3. М. Бахор // Вісник Наиіонального університету "Львівська політехніка". Серія: Електроенергетичні та електромеханічні системи. 2018. № 900. C. 15-20.

\section{References}

1. Razrabotka i issledovanie regulyatora staticheskogo tiristornogo kompensatora dlya podstantsii obshchego naznacheniya / Varetskiy Yu. Ye., Gapanovich V. G., Zhurakhovskiy A. V., Kens Yu. A. // Tezisy nauchno-tekhnicheskoy konferentsii "Sozdanie i primenenie tiristornykh preobrazovateley soizmerimoy moshchnosti". - Kharkov, 1990.

2. Gapanovich V. G. Rozrobka regulyatora statichnogo tiristornogo kompensatora dlya sistemi elektropostachannya shakhtnogo navantazhennya / V. G. Gapanovich, Z. M. Bakhor // Visnik Natsionalnogo universitetu "Lvivska politekhnika". 2016. № 840: Yelektroenergetichni ta elektromekhanichni sistemi. C. 24-30.

3. Gapanovich V. G. Metodika rozrakhunku koefitsientiv pidsilennya regulyatora statichnogo tiristornogo kompensatora / V.G. Gapanovich, Z. M. Bakhor // Visnik Natsionalnogo universitetu "Lvivska politekhnika". - 2017. № 870: Yelektroenergetichni ta elektromekhanichni sistemi. C. 22-26.

4. Xiao-Ping Z., Rehtanz C., Bikash P. (2006): Flexible AC Transmission Systems: Modelling and Control. 395 p. Chap.2, Springer Berlin Heidelberg New York. - Peжим docmyny: http://www.springer.com/gp/book/9783642282409.

5 Hirofumi Akagi. Instantaneous power theory and applications to power conditioning / A. Hirofumi, E. Hirokazu Watanabe, A. Mauricio. New York (USA): IEEE Press book, 2007. 389 p. Режим доступу: http://www.gbv.de/dms/ilmenau/toc/522443818.PDF. 
6. Miranda Vladimiro. An improved Fuzzy Inference System for Voltage/VAR control // IEEE Transactions on Power Systems, vol. 22, No. 4, November 2007. - Peжuм docmyny: https://docslide.us/documents/an-improved-fuzzy-inferencesystem-for-voltagevar-control.html.

7. Modelling and Simulation of Static VAr Compensator (SVC) in Power System Studies by MATLAB / Houari Boudjella, Fatima Zohra Gherbi and Fatiha Lakdja // ACTA ELECTROTEHNICA, vol. 49, Number 4, 2008. P. 450-457. Pежим docmyny: http://www.academia.edu/3411369/Modeling_and_simulation_of_static_var_compensator_with_Matlab.

8. Mark Ndubuka. NWOHU Department of Electrical/Computer Engineering, Federal University of Technology, Minna, Niger State, Nigeria. Voltage Stability Improvement using Static Var Compensator in Power Systems // Leonardo Journal of Sciences, Issue 14, January-June 2009. P. 167-172. - Peжuм docmyny: http://ljs.academicdirect.org.

9. Karpagam N., Devaraj D. Fuzzy Logic Control of Static Var Compensator for Power System Damping // International Journal of Electrical and Electronics Engineering, 3:10 2009. P. 625-631. - Pежим доступу: http://www.iust.ac.ir/find.php?item=35.8890.13122.en

4. Ghapanovych V. Gh. Eksperymentaljni doslidzhennja procesu reghuljuvannja statychnogho tyrystornogho kompensatora dlja systemy elektropostachannja shakhtnogho navantazhennja / V. Gh. Ghapanovych, Z. M. Bakhor // Visnyk Nacionaljnogho universytetu "Ljvivsjka politekhnika”. Serija: Elektroenerghetychni ta elektromekhanichni systemy. - 2018. № 900. - C. 15-20.

V. G. Gapanovych
Lviv Polytechnic National University,
Department of Electric Power Engineering and Control Systems,
gapanovich@ukr.net

Z. M. Bakhor

Lviv Polytechnic National University, Department of Electric Power Engineering and Control Systems, zbakhor@gmail.com

\author{
EXPERIMENTAL INVESTIGATION OF THE DYNAMIC \\ PROCESSES OF A STATIC THYRISTOR COMPENSATOR \\ FOR A MINE LOAD POWER SUPPLY SYSTEM
}

(C) Gapanovych V. G., Bakhor Z. M., 2019

In order to improve quality of electrical energy in a $35 \mathrm{kV}$ power supply network of a mining load, which feeds from busbars of district substation $330 / 220 / 110 / 35 \mathrm{kV}$ "Novovolynska" of the Western regional electrical system, the static thyristor compensator of reactive power (STC) has been implemented. Conjoint operation of the STC and on-load voltage regulation device of a transformer of the substation allows resolving a task of comprehensive control of the whole power supply system (PSS) of the mining load. The authors have developed the structure diagram of the proportional regulator of the STC, which allows stabilizing voltage at the connection point with high level of precision, have been developed. To evaluate quality of the transitive process caused by perturbations of the operational mode parameters of the PSS of the mining load, the transfer function of the regulator of the STC has been brought out. The transfer function counts particular transfer function of all elements of it. For the taken values of a time constant of an active filter of the experimental model of the regulator, it is shown that transient process in its circuits goes asymptotically to the time constants. The experimental investigation of dynamic characteristics of the STC controlled by the designed regulator has proved that stable operation of STC is ensured for the whole range of attenuation time constant of the regulator.

Key words: electrical power supply system of a mining load; static thyristor compensator; dynamic characteristics. 